\title{
LEARNING THE CHINIOTI WAY: EXPLORING THE LEGACY OF A FAMILY BUSINESS COMMUNITY LEADERS' SUCCESS BASED ON THE ENTREPRENEURIAL MINDSET AND VALUES OF CHINIOTI SHEIKHS
}

\author{
Asma Abdul Rahim Ghang \\ Mohammad Ali Jinnah University, (Pakistan). \\ E-mail: asma.rahim@jinnah.edu ORCID: https:// orcid.org/0000-0001-8477-4561 \\ Jawaid A. Qureshi \\ Shaheed Zulfikar Ali Bhutto Institute of Science \& Technology (SZABIST), (Pakistan). \\ E-mail: jawaid.qureshi@szabist.edu.pk ORCID: https://orcid.org/0000-0001-6380-5402 \\ Shehla Najib \\ Shaheed Zulfikar Ali Bhutto Institute of Science \& Technology (SZABIST), (Pakistan). \\ E-mail: shehlanajib@szabist.edu.pk ORCID: https:/ / orcid.org/0000-0003-1386-0002 \\ Faryal Salman \\ Institute of Business \& Health Management, Dow University, (Pakistan). \\ E-mail: faryal.salman@duhs.edu.pk ORCID: https://orcid.org/0000-0001-8477-4561
}

Recepción: 02/06/2021 Aceptación: 20/07/2021 Publicación: 24/08/2021

Gitación sugerida:

Chang, A. A. R., Qureshi, J. A., Najib, S., y Salman, F. (2021). Learning the Chinioti way: exploring the legacy of a family business community leaders' success based on the entrepreneurial mindset and values of Chinioti Sheikhs. 3C Empresa. Investigación y pensamiento crítico, 10(3), 109-135. https://doi.org/10.17993/3cemp.2021.100347.109-135 


\section{ABSTRACT}

The Chinioti Sheikh community ranks among the most successful business communities in Pakistan, yet literature is almost barren of any study that aims to understand the success model of such business communities in the country. The purpose of this paper is twofold: one is to understand the factors that make Chinioti Sheikhs a successful business community in Pakistan and second is to comprehend the role of entrepreneurial mindset and values in the contribution of entrepreneurial success for Chinioti Sheikhs in particular and other entrepreneurs in general. The study is qualitative in nature and utilizes two research methods i.e., cumulative case study and focus group for the purpose of triangulation and profound understanding. The study takes help of the book 'Kamyab Log' for analyzing cases of Chinioti Sheikh entrepreneurs and in the second phase of research, a focus group is conducted of subject experts and entrepreneurs. The findings reveal that there are a number of factors that influence success of a venture. For Chinioti Sheikhs, these factors are a combination of collective traits shared among all members of community as well as individual traits, which include a value-infused personality traits plus entrepreneurial mindset of that individual entrepreneur.

\section{KEYWORDS}

Family Business Leaders, Entrepreneurial Mindset, Entrepreneurial Values, Chinioti Sheikhs. 


\section{INTRODUCTION}

While Pakistan has witnessed a surge in entrepreneurial activities only recently, there are some business communities that have existed even before the period of partition (Akbar, 2017). The Chinioti Sheikh community is one of such communities. The indigenous literature, however, is almost barren of any studies to understand the success model of such business communities in the country. The purpose of this paper is twofold: one is to understand the factors that make Chinioti Sheikhs a successful business community in Pakistan and second is to comprehend the role of entrepreneurial mindset as well as values in the contribution of entrepreneurial success for Chinioti Sheikhs in particular and other entrepreneurs in general.

Within the subject of entrepreneurship, entrepreneurial mindset is a realm that only a few have attempted to excavate (Haynie et al., 2010; Neneh, 2012). Similarly, while one finds several studies on critical success factors of entrepreneurs (Al-Tit et al., 2019; Angel et al., 2018; Rotter, 1975; Staniewski \& Awruk, 2019), such studies have been done in isolation and only few have attempted to link entrepreneurial mindset with entrepreneurial success. The question remains: what is the role of entrepreneurial mindset in success of a venture? And do all entrepreneurs have an entrepreneurial mindset? Scholars seem to disagree (Bosman \& Fernhaber, 2018). Not all entrepreneurs are entrepreneurial and perhaps, this explains why some choose to forgo the path of entrepreneurship after taking a few strides while others persist even in the face of failure. Put differently: not all entrepreneurs have the same entrepreneurial mindset. Thus, the authors propose that entrepreneurial mindset is one of the qualities that defines a successful entrepreneur. Similarly, morality and ethical values play an important part in driving business success (Vadastreanu et al., 2015). Yet, we witness cases of fraudulent yet 'successful' entrepreneurs on daily basis, which begs the question: is morality a driver of success?

The study takes an exploratory qualitative voyage to understand how entrepreneurial mindset and moral values collaborate to drive business success. The study contributes to the existing literature by rendering a framework for entrepreneurial success where entrepreneurial mindset and entrepreneurial 
values are interweaved to form a value-based success model. Essentially, the study asked two overarching research questions: a) What are the factors that drive success for Chinioti Sheikh entrepreneurs? b) In a larger context, what is the role of entrepreneurial mindset as well as moral and ethical values in the entrepreneurial success for Chinioti Sheikhs in particular and other entrepreneurs in general?

\section{LITERATURE REVIEW}

\subsection{DEFINING ENTREPRENEURIAL MINDSET (EM)}

One of the questions that scholars working on entrepreneurship have entertained is what makes entrepreneurs entrepreneurial? While scholars like McClleland (1965) brought forth the notion that it is the personality traits that distinguish and define entrepreneurs from the mainstream, this proposition did not explain why some entrepreneurs failed to identify an opportunity and others excelled (Naumann, 2017). Thus, scholars shifted their attention towards cognition and posited that it is actually the entrepreneurial mindset that differentiates entrepreneurs from within the entrepreneurial community. Hence, it is the EM which is a defining element for a successful entrepreneur. The entrepreneurial mindset is defined as a 'growth-oriented perspective' that allows an entrepreneur to practice qualities such as creativity and innovation even in face of uncertainty (Ireland et al., 2003). It is also defined as the inclination to "discover, evaluate and exploit opportunities" (Bosman \& Fernhaber, 2018, p. 13).

Others extended the definition to add that an entrepreneur with entrepreneurial mindset has the ability to identify opportunities even in unforeseeable circumstances because of their cognitive capacity that aids them to render meaning to chunks of unstructured events. McGrath and MacMillan (2000) defined five qualities of an entrepreneur with entrepreneurial mindset: a) the keenness to search for new prospects; b) the religious chase after the prospect identified; c) the ability to seek out and chase after only the best prospects out of many; d) the emphasis on execution more than planning; and e) the tendency to direct the efforts of others towards entrepreneur's desired interest. 
The trait of focusing more on execution than planning is parallel to the definition of an effectual entrepreneur given by Sarasvathy (2004). Thus, it can be said that the entrepreneur with an entrepreneurial mindset is more of an effectual entrepreneur than causal. While some scholars have attempted to find the root cause of an entrepreneurial mindset (Haynie et al., 2010), others such as Ireland et al. (2003) posited that entrepreneurial mindset, along with other characteristics such as creativity, cultural orientation and effective management of resources all contribute in the development of strategic entrepreneurship. They proposed that entrepreneurial mindset stresses on creation of value and identification of opportunities. Some authors found that for established entrepreneurial firms such as, small and medium enterprises (SMEs), the elements of effectuation (i.e., pursuing opportunities without much planning and forecasting) and causation (i.e., pursuing opportunities after substantial planning or strategy and forecasting) theories can be combined (Reyes-Mercado \& Verma, 2020; Shirokova et al., 2021; Vanderstraeten et al., 2020). Many of them started without much planning and forecasting, but they applied such tools after a track record of success.

\subsection{ENTREPRENEURS' MORAL AND ETHICAL VALUES}

In everyday business situation, entrepreneurs face controversial or ethical dilemmas and make moral or immoral decisions (Bryant, 2009). In this regard, their personal values and moral awareness are two critical factors that regulate their decisions. Vadastreanu et al. (2015) defined twelve ethical rules that any business must follow in order to maintain a good reputation in the market. These twelve principles are: 1 ) honesty; 2) integrity; 3) keeping promises; 4) loyalty; 5) correctness; 6) care; 7) respect for others; 8) respect the law; 9) concern for excellence; 10) leadership; 11) reputation and morale; and 12) responsibility.

Elucidating the 12 principles, the scholars suggest that businesses must establish truthfulness with all their stakeholders. They must remain loyal to their stakeholders such as employees and customers and practice correctness i.e., the endeavor to remain fair and just in all matters. Furthermore, ethical firms exercise care and compassion and strive for betterment of their stakeholders. They respect others and respect the law. They are continuously striving for excellence in all their duties and responsibilities. They 
prove to be worthy leaders by being role models through their own ethical actions. Lastly, they take personal responsibility for their own actions and try to protect others from their mistakes.

\subsection{ENTREPRENEURIAL SUCCESS}

A disarray is usually observed when trying to define an indicator that best defines success. An assortment of varying indicators related to financial and non-financial metrics is seen (Francis, 2016). Some define wealth as key indicator (McMullen \& Shepherd, 2006) while others link it to non-financial indicators. Many scholars have tied entrepreneurial success to psychological factors such as personal satisfaction (Chong, 2012), high self-efficacy (Chen et al., 1998), locus of control and need for achievement (Chell, 2008; McClelland, 1965). Some studies have found that entrepreneurs with a persistent mindset tend to be visionary leaders, even if they come from non-family businesses (Qureshi et al., 2018).

Other studies report that family businesses have relatively lesser risk of failure as they are aware of the tricks of trade and business (Qureshi et al., 2018). Coming from entrepreneurial family background or having strong family support has found itself a prominent place in the list of entrepreneurial success factors (Aldrich \& Cliff, 2003; Lindquist et al., 2015; Luca \& Robu, 2016). Culture has also been identified as one of the domineering factors (Hayton et al., 2002; Laužikas \& Mokšeckienė, 2013). A study in Malaysia emphasized the significance of religious values such as honesty and need to fulfill obligations (Makhbul \& Hasun, 2011). Zulkifli and Rosli (2013) asserted that religiosity has a moderating role in the entrepreneurial success. It can be concluded that there is not a single factor but rather, a combination of factors that contribute to the success of entrepreneurial venture (Thien, 2016).

\subsection{ENTREPRENEURIAL TRAITS OF CHINIOTI SHEIKH COMMUNITY}

The Chinioti Sheikhs are among the top ranked communities known in Pakistan for their entrepreneurial inclination. Although there is scant research available on them, a remarkable work has been done to extract entrepreneurial traits of three communities i.e., Memon, Chinioti, and Delhi Saudagar (Javaid et al., 2019). The results of their findings indicate that entrepreneurs of these three communities are 
characterized by strong principles such as honesty and humility, a firm belief in their faith, eagerness for growth, and good relations with employees as well as clients, among others. They are risk-takers and perseverant. These individuals have a strong family network and support; they allow young minds into the business early on and guide them to become better business-oriented. Commitment, credibility of their business and family name, and honoring their words is most important to them.

\section{RESEARCH METHODOLOGY}

The study operates under constructivist paradigm and inductive approach. Two qualitative techniques were used i.e., cumulative case study approach and focus group. For the cumulative cases, the authors randomly selected sixteen published cases of successful entrepreneurs from the book 'Kamyab Log (Successful People)' authored by Dr. Amjad Saqib. The cases were written using personal interviews with the entrepreneurs from Chiniot Sheikh community of Pakistan (Saqib, 2016). Next, focus group of seven participants was conducted in two phases: one face-to-face and other online.

The questions for the focus group revolved around the three key themes i.e., entrepreneurial mindset, entrepreneur's moral and ethical values, and factors of success. Thus, the protocol comprised of questions that probed the participants to describe the characteristics of a successful entrepreneur; for example, and their experiences and perceptions about the entrepreneurs of Chinioti Sheikh community. Non-probability purposive sampling was used to select the participants, the criteria being that they were subject experts of entrepreneurship or were entrepreneurs themselves. The interview process ended at saturation point where the authors saw no new information emerging from probing (Bashir et al., 2017; Creswell et al., 2006). 


\section{FINDINGS}

\subsection{PHASE I: CUMULATIVE CASE STUDY}

A total of sixteen cases were analyzed and treated with cycle coding to extract themes and patterns related to entrepreneurial success. A profile of the cases analyzed from the book 'Kamyab Log' is given in Table 1. The cases contained interviews of the protagonists as well as their partners such as brothers or sons working alongside which have also been analyzed; however, the names are copied in the table as given in the book for reader's convenience.

Table 1. Profile Summary of Cases Analyzed.

\begin{tabular}{|c|c|c|c|}
\hline Sr \# & Name & Company Name / Group & Page Number in Book \\
\hline 1 & S. M. Muneer & Din Group & 67 \\
\hline 2 & S. M. Naseer & Din Group & 73 \\
\hline 3 & Mian Muhammad Abdullah & Sapphire Group & 83 \\
\hline 4 & Mian Mehboob lqbal Tata & Tata Group & 99 \\
\hline 5 & Mian Inaam llaahi & Nagina Group & 121 \\
\hline 6 & Mian Ahmed Kamal & Kamal Group & 129 \\
\hline 7 & Javed lqbal Wahra & Mayfair Group & 155 \\
\hline 8 & Sheikh Muhammad Saleem & MIMA Group & 169 \\
\hline 9 & Ahsan Saleem & Crescent Group & 183 \\
\hline 10 & Mian Muneer Manoo & Olympia Group & 189 \\
\hline 11 & Jahangir Monoo & Manoo Group & 201 \\
\hline 12 & Mian Tariq Nisar; Anjum Nisar & ATS Group & 217 \\
\hline 13 & Qaiser Ahmed Sheikh & Maiser LG Petrochemical Pvt Ltd & 225 \\
\hline 15 & Mian Muhammad Anwar & Crescent Group & 247 \\
\hline 16 & Fowad Mukhar Ahmed, Fazal Ahmed Sheikh, & Hijaz Hospital & 261 \\
\hline
\end{tabular}

Source: own elaboration. 
Carrying out a line-by-line coding, a total of twenty-five themes were extracted (appended in Appendix A), which were then categorized and reorganized to club together similar themes. A final list of themes is available with the authors as an Appendix.

\subsection{PHASE II: FOCUS GROUP SESSION}

Due to availability issue of participants at one point in time, the focus group had to be divided into two mini focus groups. The participants were entrepreneurs and operated their own businesses such as in case of participants NS, MK and SS, or were faculty members teaching entrepreneurial courses, or both in case of participant EZ. Two of the female participants had an MS degree in Management Sciences while one male participant was a PhD holder. Two male entrepreneurs both had an MBA degree and had been classmates.

While the focus group discussion upheld the findings from case study, it added a refreshing touch to some aspects of entrepreneurship that the book had overlooked. For example, the book was absent of the issues such as extortion and blackmailing faced by entrepreneurs by which they are forced to forgo their ethical principles and give money to secure their businesses.

\subsection{A COMPARATIVE ANALYSIS}

While the case study mainly focused on the Chinioti Sheikh community, the focus group centered on general characteristics of community entrepreneurs while adding new insights into the study. Both methods reported some common personality traits of entrepreneurs such as perseverance. While case study accentuated the down-to-earth attitude of Chinioti Sheikh entrepreneurs, the focus group highlighted the notion that entrepreneurs are usually aggressive when pursuing their business ideas which aids them amid criticisms during execution. Likewise, while the case study identified the risktaking attitude of entrepreneurs, the focus group discussion emphasized on the customary practice of entrepreneurs to take calculated risks. Both methods acknowledged the fact that entrepreneurs from family businesses possess a certain set of traits that are shared by all members. 
The concept of entrepreneurial mindset occupied a notable position in both methods. While the case study identified various elements of entrepreneurial mindset through real-time accounts and examples of successful entrepreneurs from the Chinioti Sheikh community, the focus group discussion centered on the definition and composition of factors that make up an entrepreneurial mindset. Both aspects, thus combined to shape a profound understanding of the concept.

The case study reflected on the philanthropic activities of Chinioti Sheikh entrepreneurs as well as the reasons for going into philanthropy in detail; the focus group discussion, however, did not touch upon this aspect much. The case study was brimming with examples of morality of the Chinioti Sheikh entrepreneurs and recognized it as a necessary pre-requisite of doing business whereas the focus group brought into the limelight the practical issues related to practicing ethical and moral values such as being compelled to pay bribe and extortion money in order to sustain their business while also accentuating on the customer-centric values more than fulfilling legal obligations. In all cases, it was established through both focus group and case study method that in the present day of social media and video-recording feature available in every cell phone, an unethical entrepreneur doesn't have a long-term survival.

Lastly, the case study accredited several factors of success, ranging from divine intervention and help from God to earning prayers and well wishes of their family members as well as those who benefited from their service and charities. The focus group discussion while cognizant of these factors, brought in the element of luck, thus emphasizing that all factors being constant, luck plays a major role in driving a business to success. Even though the book does not explicitly recognize this factor, one sees several examples throughout the cases where the entrepreneurs luckily hit upon a jackpot such as the case of those who migrated to Pakistan after independence and found a huge playing field left vacant for investment. Hence, one can say that both research methods complemented one another in enriching the understanding of the topic under study. 


\subsection{CONCEPTUAL FRAMEWORK}

In the light of the findings reported above, a conceptual framework is developed. The framework is defined along a continuum of collective and individual traits and encompasses a number of elements derived from the findings which piece together to form a successful venture in general and a Chinioti business model in particular. The elements on the top form universal traits i.e., most of the Chinioti families have these factors in common. As the framework travels downwards, the traits begin to get individually customized to entrepreneur's own strategies, actions and personality traits. Each element of the framework is elaborated below in accordance to their levels.

\subsection{LEVEL ONE}

On the topmost of the framework is the element Family Traits i.e., the qualities and habits of Chinioti Sheikhs such as unity in family, leadership skills and preference for entrepreneurship over job.

\subsubsection{FAMILY TRAITS}

While personality traits define an entrepreneur's overall persona, the Chinioti Sheikh community sustain some shared qualities that are in turn, inherent in their individual personalities. These include a respect for family values and traditions; support for community members; unity in family; and a common structure of apprenticeship. Keeping true to their practice of handing business over to younger generation early on, the apprenticeship system usually includes a bottom-up one year training program where the apprentice is sent to business premises immediately after graduating or on his/her eighteenth birthday. There, they start off the training by spending each month in different functional departments for one year before moving up the executive ladder. In some cases, the son is asked to spend a month on the gate to understand the activities of the business such as logistics and shipping; or spend a certain amount in a bazaar to understand the market. Other family traits include strong patriotic sentiments; the inclination to give back to their community as well as the country; spending sparingly and staying grounded. The community believes strongly in hard work and have inbuilt leadership skills. 
While these traits seem to be associated exclusively to Chinioti Sheikh entrepreneurs, one commonly witnesses that most family firms share a common set of characteristics (Kellermanns et al., 2012). For example, as indicated by a participant, NS regarding the Memon community, they also share some business habits that can be solely attributed to them.

"They are similar to Chiniotis in quite a deal but they know more about controlling cost. And most interestingly they are ready to do business on very minimal profit margins, which other people do not consider. They try to sell huge quantities rather than making maximum profit by selling few units."

\subsection{LEVEL TWO}

The level two encompasses two broad elements: Philosophies and Philanthropy. These are again universal traits with minimal variations in Chinioti entrepreneurs.

\subsubsection{BUSINESS PHILOSOPHY}

It was noted during the analysis that every entrepreneur is driven by a certain philosophy i.e., a belief or an approach towards his or her business that trickles down to shape principles and in turn, strategies and actions. Some of these beliefs are religious such as success is an endowment of God; or that success comes to only those who adhere to the rules set by God. Others are related to economics such as the importance of saving one's wealth for rainy days. For others yet, their business philosophies revolve around values such as credibility as in case of Mian Muhammad Anwer (Crescent Group) who believed that wealth ultimately leaves a person; yet reputation lingers but if that is gone, it never returns. Whatever the philosophy, a careful examination reveals that the strategies and actions of an entrepreneurs are reflection of their business philosophies.

\subsubsection{PHILANTHROPY}

The second element of family traits contains philanthropy. Although the Chiniotis consider themselves way behind in giving compared to other business communities like Memons, a quality that is again a 
manifestation of their humble attitude; they are very generous and regularly engage in philanthropic activities such as building a mosque or a healthcare facility. Entrusted with the obligation to give back to their community, they pay huge sums of money in charity and Zakat (an Islamic tax given by rich to poor) in addition to other activities such as forming non-profit organizations to bring a positive change in the society.

A probable reason for their immense interest in serving other people is mirrored in an observation made by Ahsan Saleem (Crescent Group) who asserted, "wealth loses its lust after a certain period of time. Then it has to be earned for others."

\subsection{LEVEL THREE}

Philosophies and Philanthropy trickle down into Business Rules/Principles and Business Model. Although almost all Chinioti Sheikh entrepreneurs have communal business rules and business model, both of these elements differ in terms of founder's individual ideas as well as the organizational culture of that business group, hence, the reason for being located at the midway of the continuum.

\subsubsection{PRINCIPLES OF DOING BUSINESS}

Inspired by the business philosophies, these are the rules of the game that are typically set by the elders of the family and include guidelines for doing business that the next generation obligates itself to abide by. Some of these include having a constant diversity in business; a preference for change and avoiding the status quo; an environment of continuous learning where the entrepreneurs must keep themselves updated with the latest tools and technology; spending frugally; playing a fair competition with rivals; hard work; and cherishing values such as honesty and credibility; trustworthiness and transparency among partners; in addition to staying within the limits of law; avoiding illegal sources of income and belief in God. 


\subsubsection{BUSINESS MODEL}

In addition to business principles, each family business follows a certain business model. This model encompasses a framework on how to structure their business setup. The business model of Chinioti Sheikhs typically stands on four pillars: a) delegation (of authority and power to subordinates), b) decentralization (sharing decision-making authority with individual units), c) diversification (of business to tap emerging opportunities), and d) stakeholders' interests (concerns and priorities for businesses). Although the first three factors are given utmost priority, a business augments to a status of worship in their view when the fourth pillar is added.

\subsection{LEVEL FOUR}

The lowest level contains two broad elements which are Personal Traits and Entrepreneurial Mindset. Once again, while entrepreneurs share a common set of personality traits, it is the combination of both personality traits as well as entrepreneurial mindset that define the overall persona of a business.

\subsubsection{PERSONALITY ATTRIBUTES}

A close examination of the qualities discussed during focus group as well as observed in the case study reveal that the personal qualities can be further categorized into sub-categories, i.e., personal traits and behavioral traits.

\subsubsection{PERSONAL TRAITS}

Consistent with the trait theories (Schumpeter, 1934), all the entrepreneurs analyzed seem to have a similar set of personality traits; such as flexibility and optimism. A character sketch of Chinioti Sheikhs reveals traits such as humility and humbleness, staying grounded and leading a simple lifestyle. Although a major chunk of their later generations began to prefer a luxurious lifestyle, they still avoid excessive pomp and show-off as one of their elders advised them: "Business must be done in silence and backdrop and always away from fame". 
All the entrepreneurs from the case analysis are strong followers of religion and believe in values such as honesty, trustworthiness, keeping promises, and earning a Halal (i.e., permissible and/or legal in Islam) income. Applying these traits to entrepreneurs in general, a similar pattern is found: passion and a strong belief system, whether it is an entity like God, a role model or their own selves. They are perseverant in achieving their goals and have the ability to get back on their feet after facing a loss.

\subsubsection{BEHAVIORAL TRAITS}

A common aspect of behavioral trait found in all Chinioti entrepreneurs was the habit of travelling far and wide to search for work. This aspect of migration or traveling is a manifestation of their risk-taking behavior and the propensity towards stepping out of their comfort zone. Another trait found common in all entrepreneurs is that they are people oriented; they take help of their community members in case of Chinioti Sheikhs or their friends and family in general. They are opportunists and go where the opportunity leads them. They are innovative and experimental; and are aware of their target market as well as their competitors.

\subsubsection{ENTREPRENEURIAL MINDSET (EM) AND BUSINESS INSIGHTS}

Having been born and raised in a business environment where they grow up to witness discussion related to business, business understanding and acumen becomes an innate quality for many Chinioti Sheikh community members. As in their own words, "business is our second nature." There are many aspects of EM that could be easily identified from the case analysis and attributed to a successful entrepreneur in general from the focus group. For example, when the authors inquired participants what they perceive about EM in the focus group, a series of varying opinions came out which defined and set the composition of entrepreneurial mindset. Some believed that the entrepreneurial mindset was a pre-condition of starting a business; an attitude or a way of approaching opportunities around. 
A further elaboration of this was that it was a childlike approach of an entrepreneur towards his goal e.g., the nonchalant and fearless attitude when the child climbs a tree and doesn't look down. It is the ability to focus on entrepreneur's affordable loss rather than profits and their ability to utilize their resources effectively. A true entrepreneur, in their view, is one who doesn't yearn immediate gratification but rather, has a long-term vision and the ability to foresee what others miss. In the light of the points raised above as well as the ones extracted from case study, one can assume that entrepreneurial mindset includes the attributes of opportunity orientation, strategic focus, foresightedness, and innovativeness.

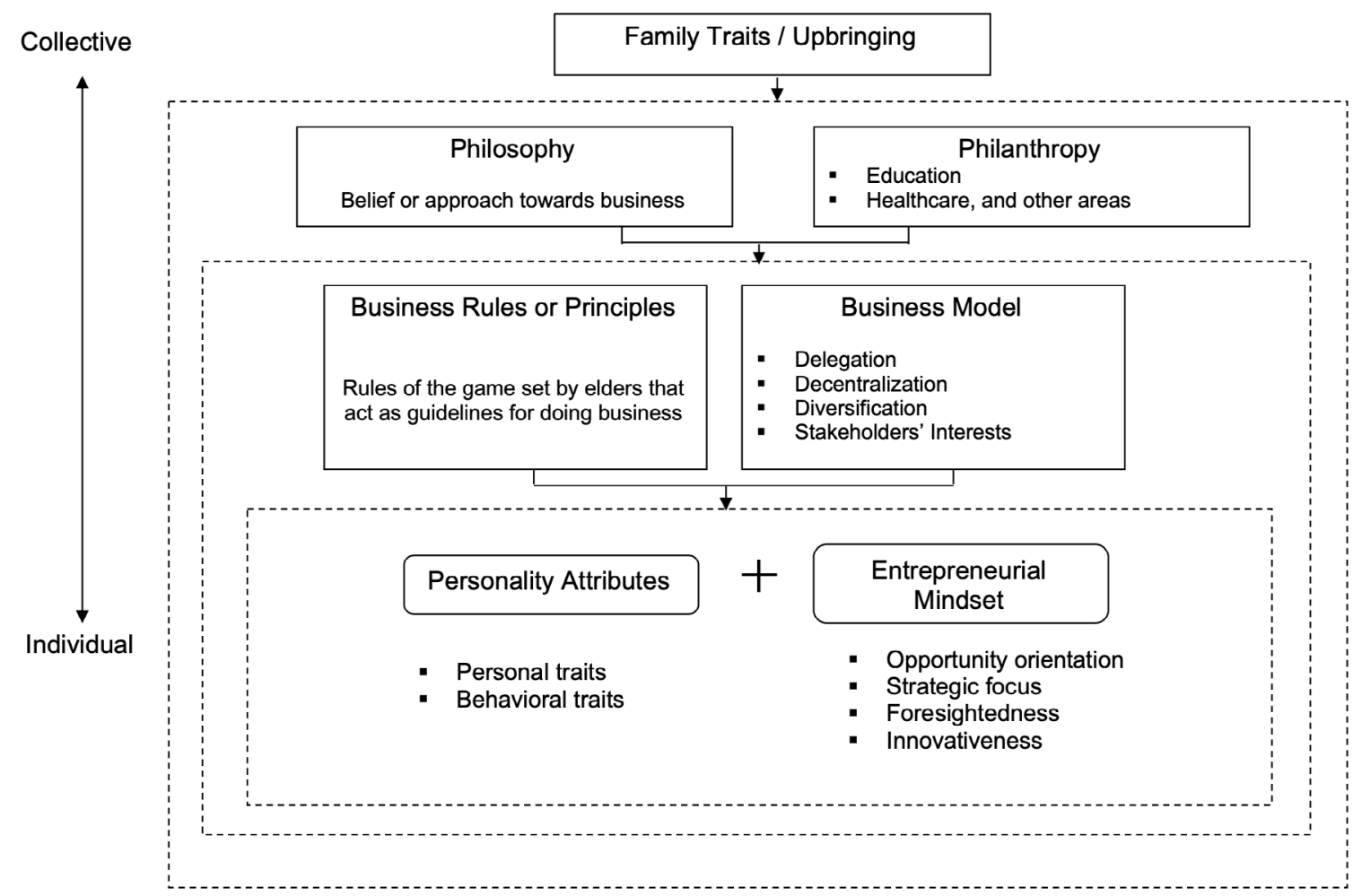

Figure 1. Conceptual Framework.

Source: own elaboration. 


\subsection{DISCUSSION}

The findings from the case study and the focus group embody the characteristics and the qualities of a successful entrepreneur, the evidences of which are found consistent with the previous studies. The fact that family entrepreneurs and more particularly community entrepreneurs are raised in a certain way coincides with many studies (Hamilton, 2011; Javaid et al., 2019). Specifically, amongst the practices of entrepreneurs from the Chinioti Sheikh community, also concurrent with the findings of Javaid et al. (2017), one can see that a similar entrepreneurial mindset and personification exists across all entrepreneurs in general.

For example, the study of Chang (2020) also report the system of apprenticeship known as entrepreneurial bridging in successful family firm entrepreneurs. Furthermore, the business rules set by the Chinioti entrepreneurs goes in hand with the twelve ethical rules described by Vadastreanu et al. (2015) that a business must comply in order to sustain their credibility in the market. Hence, one sees that they uphold values such as honesty and integrity, in addition to keeping promises, expressing respect to law as well as society and giving back to their community; thereby retaining a credible position in the market and among their customers as well as suppliers. Likewise, the personification of an entrepreneur once again affirms the findings from the literature.

The personal and the behavioral traits reported in the findings altogether depict an ideal list of characteristics that an entrepreneur typically possesses and while Gartner (1988) criticized the practice of trying to measure personality traits of an entrepreneur, it is empirically proven that an entrepreneur's personality traits influence the performance of their venture (Zhang \& Bruning, 2011). The trait of perseverance and determination also affirms a previous study of Chang (2017) who found through personal interviews with successful entrepreneurs that all her participants cherished and advocated these traits. 
On the other hand, while it is conveniently assumed that an entrepreneur is a risk-taker, we found evidences from the findings that the Chinioti Sheikh entrepreneurs as well as others believe in taking calculated risks, a finding underlined by Chell (2008). Similarly, a common characteristic found in all Chinioti Sheikh entrepreneurs was that they started small; thus, most of their characteristics corresponded with three out of five principles of effectuation (Sarasvathy, 2001), i.e., bird in hand (in terms of starting with their means), affordable loss (in terms of taking calculated risk), and crazy quilt (forming partnerships and taking help from community members). However, sometimes when they explore a lucrative opportunity, they diversify their family business (called lemonade principle) and start a new venture (called pilot in the plane) in effectuation theory, which provide them new means and new goals.

The attributes of an entrepreneurial mindset raised during the discussion as well as dug out from the case analysis all accord to effectuation theory and model found in literature (Qureshi et al., 2016). Thus, one saw that it is a growth-oriented perspective since a successful entrepreneur hates stagnation or lack of growth and is actively engaged in seeking opportunities to expand his or her venture. The successful cases of Chinioti Sheikh entrepreneurs also resonate with the fact that it is entrepreneurial mindset indeed which is a function of entrepreneurial success.

The eagerness of the Chinioti Sheikh entrepreneurs in philanthropic activities also resonates with the phenomenon of entrepreneurial philanthropy (Harvey et al., 2011) who define the term as an entrepreneur's desire to tackle social issues through active involvement and investment of their wealth, time and effort. A significant addition to this links entrepreneurial success to entrepreneurial philanthropy, which using the definition of success as an accumulation of significant wealth or profits from their business, suggests that such successful entrepreneurs when engage in philanthropic activities invest momentous resources and capital to bring about a positive change (Shaw et al., 2013). This finding accords with the practices of Chinioti Sheikh entrepreneurs who, besides their wealth, also dedicate their time and energies to build universities and educational institutes, healthcare facilities and religious centers; rather than just giving in charity. 
An interesting addition to the findings is the disclosure of unethical practices that ethical entrepreneurs are forced to do such as paying bribe or extortion money to government officials or mafia groups to sustain their business or get an administrative task done. Although amusing, it is not surprising as Pakistan Corruption Report indicates a high corruption risk in the country and a severe obstacle to businesses in general (The Risk \& Compliance Portal, 2017). Such a dysfunctional environment can hinder business success as many entrepreneurs would go through the torturous dilemma of either compromising their values or their business.

\section{CONCLUSIONS AND IMPLICATIONS}

Although the authors commenced the study in search for a different kind of result, the findings took a new course of direction on its own. The authors hoped to learn the secret of success from the business community of Chinioti Sheikhs and generalize the findings to larger population of entrepreneurs, the study unearthed a plethora of gems that the authors investigated.

The Chinioti Sheikhs are successful because they follow a sophisticated system comprising of words of wisdom from their elders along with training, network of religious beliefs, and a value system sitting on ethics and morality. Moreover, the upbringing and an organized apprenticeship program helps shape their business acumen. Thus, they grow up with personality ingrained with leadership skills, creativity, and business insights. It is this combination of their value-infused personality and entrepreneurial mindset that becomes the ultimate driver of success of their business. Hence, to answer the question if entrepreneurial mindset is enough, then it certainly is not. Is this business model confined to Chinioti Sheikhs only and whether an entrepreneur from a nonfamily business learn nothing from it? The focus group discussion contradicts it.

Hence, although an entrepreneur who does not come from an entrepreneurial family may face a different environment at home, they may have a certain philosophy and business model that may orient their direction into entrepreneurial action. In case their actions are absent from it, the framework can 
act as a model to follow as one learns that values are as significant as strategy building, thus the heart and the mind. Finally, the study presents a conceptual framework that contains factors like business philosophy, (strong desire for) philanthropy, business rules or principles (learnt from elders), business model (comprising sub-factors, delegation, decentralization, diversification, and stakeholders' interests), personality traits, and entrepreneurial mindset (comprising sub-factors, opportunity, strategic focus, strategies and innovation, and foresight and decision-making).

\subsection{AREAS FOR FUTURE STUDY}

Since the study is purely exploratory in nature, it offers an array of opportunities for empirical advances. Moreover, since the study is first of its kind in its attempt to do an in-depth study of the entrepreneurial practices of a prominent business community in Pakistan, further studies can be pursued in this direction. For example, a comparative study can be done between entrepreneurs coming from entrepreneurial family background versus non-entrepreneurial background to compare and contrast the difference in their business approach and perception of success. Likewise, a comparative study on the business model of Chinioti Sheikh community and other business communities such as Memon and Agha Khanis can be carried out to investigated.

The study can also be advanced using other methods within qualitative domain such as interviews of successful entrepreneurs to get their accounts and perception about the framework and the results of the study. On the other hand, a quantitative approach can be taken to understand success. A primary work can be done on further enhancement and testing of the framework put forward in this study as well as developing a theory of entrepreneurial success. Thus, theory building could be done after soliciting data from a larger sample. Furthermore, the study can be replicated in other cities of Pakistan and even outside the country for an enriched conceptualization. 


\section{REFERENCES}

Al-Tit, A., Omri, A., \& Euchi,J. (2019). Critical success factors of small and medium-sized enterprises in Saudi Arabia: Insights from sustainability perspective. Administrative Sciences, 9(2), 32. https:// www.researchgate.net/publication/347535652_Critical_Success_Factors_of_Small_and_ Medium-Sized_Enterprises_in_Saudi_Arabia_Insights_from_Sustainability_Perspective

Angel, P., Jenkins, A., \& Stephens, A. (2018). Understanding entrepreneurial success: A phenomenographic approach. International Small Business Fournal, 36(6), 611-636. https://doi. org/10.1177/0266242618768662

Bashir, S., Syed, S., \& Qureshi, J. (2017). Philosophical and methodological aspects of mixedmethods research: A review of the academic literature. Fournal of Independent Studies and Research, 15(1), 32-50. http://jisr.szabist.edu.pk/JISR-MSSE/Publication/2017/15/1/499/Article

Bosman, L., \& Fernhaber, S. (2018). Defining the entrepreneurial mindset. In L. Bosman \& S. Fernhaber (Eds.), Teaching the Entrepreneurial Mindset to Engineers (pp. 7-14). Springer International Publishing.

Bryant, P. (2009). Self-regulation and moral awareness among entrepreneurs. Fournal of Business Venturing, 24(5), 505-518. https://doi.org/10.1016/j.jbusvent.2008.04.005

Ghang, A. A., Mubarik, M. S., \& Naghavi, N. (2020). Passing on the legacy: Exploring the dynamics of succession in family businesses in Pakistan. Journal of Family Business Management, (ahead-ofprint).

Chell, E. (2008). The entrepreneurial personality: A social construction (2nd ed.). Routledge. 
Ghen, G. G., Greene, P. G., \& Grick, A. (1998). Does entrepreneurial self-efficacy distinguish entrepreneurs from managers? Journal of Business Venturing, 13(4), 295-316. https://econpapers. repec.org/article/eeejbvent/v_3a13_3ay_3a1998_3ai_3a4_3ap_3a295-316.htm

Chong, W. (2012). Critical success factors for small and medium enterprises: Perceptions of entrepreneurs in Urban Malaysia. Journal of Business and Policy Research, 7(1), 204-215. https:// www.semanticscholar.org/paper/Critical-Success-Factors-for-Small-and-Medium-of-in-Chong/ a657557b849269feab61447a17a04023b9d2469d

Greswell, J. W., Shope, R., Plano Clark, V. L., \& Green, D. O. (2006). How interpretive qualitative research extends mixed methods research. Research in the Schools, 13(1), 1-11. https://www. researchgate.net/publication/228435302_How_interpretive_qualitative_research_extends_ mixed_methods_research

Francis, P. A. (2016). Factors that led to entrepreneurial success: An exploratory qualitative study [PhD Thesis]. Capella University.

Gartner, W. B. (1988). "Who is an entrepreneur?" Is the wrong question. American fournal of Small Business, 12(4), 11-32. https://journals.sagepub.com/doi/10.1177/104225878801200401

Hamilton, E. (2011). Entrepreneurial learning in family business: A situated learning perspective. Journal of Small Business and Enterprise Development, 18(1), 8-26. https://www.emerald.com/insight/ content/doi/10.1108/14626001111106406/full/html

Harvey, C., Maclean, M., Gordon, J., \& Shaw, E. (2011). Andrew Carnegie and the foundations of contemporary entrepreneurial philanthropy. Business History, 53(3), 425-450. https://doi.org/10. 1080/00076791.2011.565516 
Haynie, J. M., Shepherd, D., Mosakowski, E., \& Earley, P. G. (2010). A situated metacognitive model of the entrepreneurial mindset. Fournal of Business Venturing, 25(2), 217-229. http: / / citeseerx. ist.psu.edu/viewdoc/download?doi=10.1.1.454.5117\&rep=rep 1\&type=pdf

Hayton, J. G., George, G., \& Zahra, S. A. (2002). National culture and entrepreneurship: A review of behavioral research. Entrepreneurship Theory and Practice, 26(4), 33-52. https://journals.sagepub. com/doi/10.1177/104225870202600403

Ireland, R. D., Hitt, M. A., \& Sirmon, D. G. (2003). A model of strategic entrepreneurship: The construct and its dimensions. Fournal of Management, 29(6), 963-989. https://psycnet.apa.org/ record/2003-10883-004

Javaid, O., Shamsi, A., \& Hyder, I. (2019). How Memon, Delhi Saudagaran and Chinioti Entrepreneurs Create New Ventures? Pakistan Business Review.

Kellermanns, F. W., Eddleston, K. A., \& Zellweger, T. M. (2012). Article Commentary: Extending the Socioemotional Wealth Perspective: A Look at the Dark Side. Entrepreneurship Theory and Practice, 36(6), 1175-1182. https://journals.sagepub.com/doi/abs/10.1111/j.1540-6520.2012.00544.x

Laužikas, M., \& Mokšeckienè, R. (2013). The role of culture on entrepreneurship in Lithuania. Socialiniai Tyrimai, 2(31), 55-69. https://vb.mruni.eu/object/elaba:6092663/

Lindquist, M.J., Sol,J., \& Van Praag, M. (2015). Why do entrepreneurial parents have entrepreneurial children? Journal of Labor Economics, 33(2), 269-296. https://econpapers.repec.org/article/ ucpjlabec/doi_3a10.1086_2f678493.htm

Luca, M., \& Robu, A. (2016). Personality traits in entrepreneurs and self-employed. Bulletin of the Transilvania University of Brasov, 9. https://www.researchgate.net/publication/312320488_ PERSONALITY_TRAITS_IN_ENTREPRENEURS_AND_SELF-EMPLOYED 
Makhbul, Z. M., \& Hasun, F. M. (2011). Entrepreneurial success: An exploratory study among entrepreneurs. International Fournal of Business and Management, 6(1), 116-125. https://www.ccsenet. org/journal/index.php/ijbm/article/view/7046

McGlelland, D. G. (1965). Toward a theory of motive acquisition. American Psychologist, 20(5), 321-333. https://psycnet.apa.org/record/1965-13693-001

McGrath, R. G., \& MacMillan, I. G. (2000). The entrepreneurial mindset: Strategies for continuously creating opportunity in an age of uncertainty. Harvard Business Press.

McMullen, J. S., \& Shepherd, D. A. (2006). Entrepreneurial action and the role of uncertainty in the theory of the entrepreneur. Academy of Management Reviere, 31(1), 132-152. https://doi. org/10.5465/amr.2006.19379628

Naumann, G. (2017). Entrepreneurial mindset: A synthetic literature review. Entrepreneurial Business and Economics Review, 5(3), 149-172. https://eber.uek.krakow.pl/index.php/eber/article/view/292

Neneh, N. B. (2012). An exploratory study on entrepreneurial mindset in the small and medium enterprise (SME) sector: A South African perspective on fostering small and medium enterprise (SME) success. African Fournal of Business Management, 6(9), 3364-3372.

Qureshi, J., Qureshi, M. S., \& Qureshi, M. A. (2018). Mitigating risk of failure by expanding family entrepreneurship and learning from international franchising experiences of Johnny Rockets: A case study in Pakistan. International Journal of Experiential Learning \& Case Studies, 3(1), 110 127. https://journals.iobmresearch.com/index.php/JELCS/article/view/1972 
Qureshi, J., Qureshi, M. S., \& Talha, M. (2018). A visionary leader and an entrepreneur with persistent mind-set: Jahangir Siddiqui (Founder of JS Bank and Group of Companies). International Fournal of Multidisciplinary Thought, 7, 207-220. https://www.researchgate.net/ publication/349644895_A_VISIONARY_LEADER_AND_AN_ENTREPRENEUR_WITH_ PERSISTENT_MIND-SET_JAHANGIR_SIDDIQUI_FOUNDER_OF_JS_BANK_AND_ GROUP_OF_COMPANIES

Qureshi, S., Ghang, A. A., \& Shahid, A. (2016). Women entrepreneurs in Pakistan: A qualitative study using multiple case design method to study the application of effectuation model. Global Management Fournal for Academic $\mathcal{E}$ Corporate Studies, 6(2), 170-176.

Reyes-Mercado, P., \& Verma, R. (2020). Effectuation and causation approaches in entrepreneurial marketing: A set-theoretical model (pp. 347-361).

Rotter, J. B. (1975). Some problems and misconceptions related to the construct of internal versus external control of reinforcement. Fournal of Consulting and Clinical Psychology, 43(1), 56-67. https:// psycnet.apa.org/record/1975-11748-001

Saqib, A. (2016). Kamyab log. Sangameel Publishers.

Sarasvathy, S. D. (2001). Causation and effectuation: Toward a theoretical Shift from economic inevitability to entrepreneurial contingency. The Academy of Management Review, 26(2), 243-263. https://www.jstor.org/stable/259121

Sarasvathy, S. D. (2004). Making it happen: Beyond theories of the firm to theories of firm design. Entrepreneurship Theory and Practice, 28(6), 519-531. https://doi.org/10.1111/j.15406520.2004.00062.x

Schumpeter, J. A. (1934). The theory of economic development: An inquiry into profits, capital, credit, Interest, and the business cycle. Harvard University Press. 
Shaw, E., Gordon, J., Harvey, G., \& Maclean, M. (2013). Exploring contemporary entrepreneurial philanthropy. International Small Business fournal, 31(5), 580-599. https://doi. org/10.1177/0266242611429164

Shirokova, G., Morris, M. H., Laskovaia, A., \& Micelotta, E. (2021). Effectuation and causation, firm performance, and the impact of institutions: A multi-country moderation analysis. Fournal of Business Research, 129, 169-182. https://doi.org/10.1016/j.jbusres.2021.02.045

Staniewski, M. W., \& Awruk, K. (2019). Entrepreneurial success and achievement motivation - A preliminary report on a validation study of the questionnaire of entrepreneurial success. Fournal of Business Research, 101, 433-440. https://ideas.repec.org/a/eee/jbrese/v101y2019icp433-440. html

The Risk \& Compliance Portal. (2017). Pakistan Corruption Report. https://www.ganintegrity.com/ portal/country-profiles/pakistan/

Thien, G. (2016). The luck factor in entrepreneurship success. Fournal of Scientific Research and Development, 3(3), 82-89.

Vadastreanu, A. M., Maier, D., \& Maier, A. (2015). Is the success possible in Compliance with ethics and deontology in business? Procedia Economics and Finance, 26, 1068-1073. https://doi. org/10.1016/S2212-5671(15)00931-4

Vanderstraeten, J., Hermans, J., Witteloostuijn, A. van, \& Dejardin, M. (2020). SME innovativeness in a dynamic environment: Is there any value in combining causation and effectuation? Technology Analysis \&ै Strategic Management, 32(11), 1277-1293. https://doi.org/10.1 080/09537325.2020.1766672 
Zhang, D., \& Bruning, E. (2011). Personal characteristics and strategic orientation: Entrepreneurs in Canadian manufacturing companies. International Journal of Entrepreneurial Behavior \& Research, 17(1), 82-103. https://www.emerald.com/insight/content/doi/10.1108/13552551111107525/ full/html

Zulkifli, R. M., \& Rosli, M. M. (2013). Entrepreneurial orientation and business success of Malay entrepreneurs: Religiosity as moderator. International fournal of Humanities and Social Science, 3(10), 264-275. http://www.ijhssnet.com/journals/Vol_3_No_10_Special_Issue_May_2013/29.pdf 